\title{
EFFECTS OF CONTROLLED - RELEASE POTASH FERTILIZER ON GROWTH AND YIELD OF CUCUMBER IN THAI NGUYEN
}

Ha Xuan Linh ${ }^{1 *}$, Tran Quoc Toan ${ }^{2}$

${ }^{1} T N U$ - International School, ${ }^{2}$ TNU - University of Education

\begin{tabular}{|c|c|c|}
\hline \multicolumn{2}{|c|}{ ARTICLE INFO } & ABSTRACT \\
\hline Received: & $14 / 4 / 2021$ & Controlled-release fertilizers have been researched and used widely; hence, \\
\hline Revised: & $20 / 5 / 2021$ & $\begin{array}{l}\text { developing new slow or controlled-release fertilizers is very important. This } \\
\text { study was conducted in the Winter-Spring crop of } 2019 \text { to evaluate the }\end{array}$ \\
\hline Published: & $21 / 5 / 2021$ & effects of controlled release potassium fertilizers on the growth, \\
\hline \multicolumn{2}{|l|}{ KEYWORDS } & Thai Nguyen province. The study was arranged in a complete randomized \\
\hline \multicolumn{2}{|c|}{ Cucumis sativus $\mathrm{L}$} & fertilizer formulations with different doses of $120 \mathrm{~kg} \mathrm{~K} \mathrm{~K}_{2} \mathrm{O} / \mathrm{ha}, 84 \mathrm{~kg}$ \\
\hline \multicolumn{2}{|c|}{ Controlled-release fertilizer } & $\mathrm{K}_{2} \mathrm{O} / \mathrm{ha}$, and $60 \mathrm{~kg} \mathrm{~K} \mathrm{~K}_{2} \mathrm{O} / \mathrm{ha}$ were used to compare with the control formula \\
\hline \multicolumn{2}{|c|}{ Potash } & $\begin{array}{l}\text { using conventional fertilizer }\left(120 \mathrm{~kg} \mathrm{~K}_{2} \mathrm{O} / \mathrm{ha}\right) \text {. Research results show that } \\
\text { the formula using controlled-release fertilizer with a dosage of } 84 \mathrm{~kg}\end{array}$ \\
\hline \multicolumn{2}{|l|}{ Growth } & 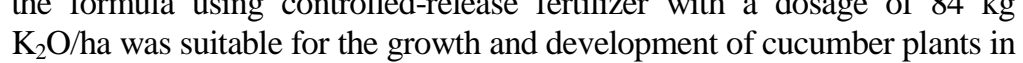 \\
\hline \multicolumn{2}{|l|}{ Development } & Dong Hy district, Thai Nguyen province. At this formula, even the time of \\
\hline \multicolumn{2}{|l|}{ Yield } & $\begin{array}{l}\text { plant growing was the longest ( } 70 \text { days), it still gave the highest figure in } \\
\text { numbers of fruits/ plant }(2.91) \text {, fruit length }(20.13 \mathrm{~cm}) \text {, fruit diameter }(4.16 \\
\mathrm{cm}) \text {, flesh thickness }(1.36 \mathrm{~cm}) \text {, and the highest actual yield }(19.81 \text { tons } / \mathrm{ha}) \text {. } \\
\text { Besides, with the rate of applying } 84 \mathrm{~kg} \text { controlled fertilizer/ha, plant have } \\
\text { the best ability in resistance to pest and diseases. }\end{array}$ \\
\hline
\end{tabular}

\section{ẢNH HƯởNG CỦA PHÂN KALI NHẢ CHẬM ĐẾN SINH TRƯởNG, PHÁT TRIỂN VÀ NĂNG SUÁT CỦA CÂY DƯA CHUỘT TẠI THÁI NGUYÊN}

Hà Xuân Linh ${ }^{1^{*}}$, Trần Quốc Toàn ${ }^{2}$

${ }^{1}$ Khoa Quốc tế - ĐH Thái Nguyên, ${ }^{2}$ Truòng Đại học Su phạm - ĐH Thái Nguyên

\begin{tabular}{|c|c|c|}
\hline \multicolumn{2}{|c|}{ THÔNG TIN BÀI BÁO } & TÓM TẮT \\
\hline Ngày nhận bài: & $14 / 4 / 2021$ & Phân bón nhả chậm có kiểm soát đã được nghiên cứu và sử dụng ngày \\
\hline Ngày hoàn thiện: & $20 / 5 / 2021$ & $\begin{array}{l}\text { càng rộng rãi, việc phát triển các loại phân nhả chậm hoặc có kiểm soát } \\
\text { mới là rất quan trong. Nghiên cứu này được thực hiện vào vu Đông - }\end{array}$ \\
\hline Ngày đăng: & 21/5/2021 & Xuân năm 2019 để đánh giá ảnh hưởng của phân bón kali nhả chậm đến \\
\hline & & sinh trưởng, phát triển và năng suất dưa chuột Amata765 trồng tại huyện \\
\hline \multicolumn{2}{|l|}{ TÙ KHÓA } & Đồng Hỷ, tỉnh Thái Nguyên. Nghiên cứu được bố trí theo phương pháp \\
\hline \multicolumn{2}{|l|}{ Dưa chuột } & phân bón nhả chậm với các liều lượng khác nhau là $120 \mathrm{~kg} \mathrm{~K}_{2} \mathrm{O} / \mathrm{ha}, 84$ \\
\hline \multicolumn{2}{|l|}{ Phân nhả chậm } & $\mathrm{kg} \mathrm{K} \mathrm{K}_{2} \mathrm{O} / \mathrm{ha}$, và $60 \mathrm{~kg} \mathrm{~K}_{2} \mathrm{O} /$ ha được sử dụng để so sánh với công thức đối \\
\hline \multirow{2}{*}{\multicolumn{2}{|c|}{ Kali }} & chứng sử dụng phân thông thường $\left(120 \mathrm{~kg} \mathrm{~K} \mathrm{~K}_{2} \mathrm{O} / \mathrm{ha}\right)$. Kết quả nghiên cứu \\
\hline & & cho thấy công thức sử dụng phân bón nhả chậm với liều lượng $84 \mathrm{~kg}$ \\
\hline \multicolumn{2}{|l|}{ Sinh trưởng } & $\mathrm{K}_{2} \mathrm{O} /$ ha phù hợp cho sự sinh trưởng, phát triển của cây dưa chuột tại \\
\hline \multicolumn{2}{|l|}{ Phát triển } & huyện Đồng Hỷ, tỉnh Thái Nguyên. Tại công thức này, mặc dù thời gian \\
\hline \multirow{4}{*}{\multicolumn{2}{|c|}{ Năng suất }} & sinh trưởng cần lâu nhất ( 70 ngày), kết quả ghi nhận các chỉ số về tăng \\
\hline & & trưởng cao nhất như số quả cho một cây $(29,1)$, độ dài của quả $(20,13$ \\
\hline & & $\mathrm{cm})$, đường kính của quả $(4,16 \mathrm{~cm})$, và độ dày thịt của quả $(1,36 \mathrm{~cm})$. \\
\hline & & $\begin{array}{l}\text { Bên cạnh đó, tại công thức này còn ghi nhận năng suất thực thu cao nhất } \\
(19,81 \text { tấ/ha) trong cả } 4 \text { công thức thí nghiệm. }\end{array}$ \\
\hline
\end{tabular}

DOI: https://doi.org/10.34238/tnu-jst.4346

\footnotetext{
* Corresponding author. Email: haxuanlinh@tnu.edu.vn
} 


\section{Introduction}

Cucumber (Cucumis sativus L) belongs to the cucurbit family (Cucurbitaceae), is a fruit vegetable that can be grown in many crop seasons a year, with a high yield. Cucumber contains many nutrients such as protein, carotene, vitamins and minerals, used in many different forms such as fresh fruit, salad dressing, sliced, canned for export... In Vietnam, cucumbers are grown in many different localities and many specialized farming areas, with low investment costs but high economic efficiency [1], [2]. During growing period, cucumbers absorb potassium most strongly, then nitrogen. Potassium helps plants to be hard and firm, contributing to increase yield and fruit quality, increase pest and disease resistance [3].

Thai Nguyen is a northern midland and mountainous province with favorable natural and soil conditions for cultivating vegetables in the direction of trading goods. In recent years, Thai Nguyen province has expanded the area of growing vegetables, from 12,500 ha in 2015 to 15,000 ha in 2020; besides, the scientific and technical advances have been actively applied to agricultural production to increase productivity. However, the yield and quality of vegetables in general and cucumbers in particular are not stable due to the effects of climate change, pests and diseases [4].

Fertilizer is an indispensable demand for crops, plays an important role in increasing productivity and quality of agricultural products. However, low fertilizer use efficiency (30-50\%) has increased production costs, negatively affecting the environment and human health. Utilizing controlled-release fertilizers is an effective solution to reduce nutrient loss and improve crop yield and quality [5]. The potential of using controlled-release fertilizers in agricultural production is huge [6] - [9], however, the application of controlled-release fertilizers in Vietnam is not popular, especially polymer-coated controlled-release fertilizers, which have capacity of controlling speed of nutrient release through polymer shells [10] - [12].

Therefore, this study was conducted to evaluate the effect of a controlled-release potassium fertilizer [13], [14] on the growth and yield of cucumbers grown in Dong Hy district, Thai Nguyen province.

\section{Materials and methods}

\subsection{Materials}

Controlled-release potassium fertilizer (CRK) was manufactured at University of Education Thai Nguyen University by the technology of polymer coating and film. Fertilizer in the form of pellets has average size from 5 to $6 \mathrm{~mm}$, the main ingredient is $\mathrm{K}_{2} \mathrm{SO}_{4}, \mathrm{~K}_{2} \mathrm{O}$ content $\sim 40 \%$, nutrient release time $\sim 50$ days.

The control potassium fertilizer (from the Philippines) is fine-grained, with the main component of $\mathrm{K}_{2} \mathrm{SO}_{4}$, content of $\mathrm{K}_{2} \mathrm{O} \sim 50 \%, \mathrm{~S} \geq 17 \%$.

Variety of cucumber Amata765 was provided by the Central Seed Company.

\subsection{Research methods}

Location and time: The experiment was conducted in Tien Phong hamlet, Khe Mo commune, Dong Hy district, Thai Nguyen province from November 5, 2019 to March 28, 2020.

Experiment design: The experiment was arranged according to the complete random method, including 04 formulas, 03 repetitions. The formulas include:

Formula 1 (CT1- control): common $\mathrm{K}_{2} \mathrm{SO}_{4}$ fertilizer, $120 \mathrm{~kg} \mathrm{~K}{ }_{2} \mathrm{O} / \mathrm{ha}$.

Formula 2 (CT2): CRK, $120 \mathrm{~kg} \mathrm{~K}_{2} \mathrm{O} / \mathrm{ha}$

Formula 3 (CT3): CRK, $84 \mathrm{~kg} \mathrm{~K} 2 \mathrm{O} / \mathrm{ha}$ (70\% compared to CT2)

Formula 4 (CT4): CRK, $60 \mathrm{~kg} \mathrm{~K}_{2} \mathrm{O} / \mathrm{ha}$ (50\% compared to CT2)

The experiment had a substrate $\left(90 \mathrm{~kg} \mathrm{P}_{2} \mathrm{O}_{5}+120 \mathrm{~kg} \mathrm{~N}+30\right.$ tons of microbiological organic fertilizer)/ha 
- Controlled-release potassium fertilizer was applied once after 5 days of planting, fertilizing far from the root of $10-15 \mathrm{~cm}$. Urea, phosphorus, potassium fertilizers and organic fertilizers were applied according to the process of planting of cucumber [3].

- The plot area was $20 \mathrm{~m}^{2}$. The cucumber plants were supported with stakes. Planting density was 3.3 thousands trees/ha

- Method of evaluating and monitoring indicators was based on QCVN 01-87: 2012/BNNPTNT National technical regulation on the testing of value of cultivation and use of cucumber varieties [3].

- Data collected in the experiments were synthesized and statistically processed using Excel and SAS 8.0 software.

\subsection{Monitoring indicators}

Monitoring indicators for cucumbers included growth stages (days); indicators for developmental growth; morphological structural features of the fruit; yield and yield component, pests and diseases [2].

\section{Results}

\subsection{Effects of controlled-release potassium fertilizer on growth time}

As the result shown in Table 1 , in the formulas of controlled-release fertilizer, time of appearing leaf, cirrus, first male flowers, first female flowers, first fruit collection and final fruit collection were shorter than the control formula (CT1). However, the total growing time of cucumbers tended to be longer than that of the control treatment. Thus, fruit collection time was extended when using controlled-release fertilizer; this result is suitable with the previous studies [10] - [12]. CT3 had the shortest time from sowing to collection of the first batch of fruits and the longest total growing time compared to other treatments.

Table 1. The effects of controlled-release potassium fertilizer on growth time

\begin{tabular}{ccccccccc}
\hline \multirow{2}{*}{$\begin{array}{c}\text { Fertilizer } \\
\text { formula }\end{array}$} & $\begin{array}{c}\text { Appearing } \\
\text { sprout }\end{array}$ & $\begin{array}{c}\text { Appearing } \\
\text { leaf }\end{array}$ & $\begin{array}{c}\text { Appearing } \\
\text { cirrus }\end{array}$ & $\begin{array}{c}\text { Appearing } \\
\text { first male } \\
\text { flower }\end{array}$ & $\begin{array}{c}\text { Appearing } \\
\text { first female } \\
\text { flower }\end{array}$ & $\begin{array}{c}\text { First fruit } \\
\text { harvesting }\end{array}$ & $\begin{array}{c}\text { Harvesting } \\
\text { time }\end{array}$ & $\begin{array}{c}\text { Total } \\
\text { growth } \\
\text { time }\end{array}$ \\
\hline CT1 & 4 & 15 & 19 & 26 & 32 & 43 & 63 & 67 \\
CT2 & 4 & 15 & 18 & 25 & 31 & 42 & 64 & 68 \\
CT3 & 4 & 14 & 17 & 23 & 28 & 40 & 66 & 70 \\
CT4 & 4 & 15 & 18 & 24 & 29 & 41 & 62 & 66 \\
\hline
\end{tabular}

3.2. Effects of controlled-release potassium fertilizer on growing time and development

Table 2. Effects of controlled-release potassium fertilizer on the growing time and development

\begin{tabular}{cccccccc}
\hline $\begin{array}{c}\text { Fertilizer } \\
\text { formula }\end{array}$ & $\begin{array}{c}\text { Main } \\
\text { body } \\
\text { length } \\
(\mathbf{m})\end{array}$ & $\begin{array}{c}\text { Number of } \\
\text { leaves on the } \\
\text { main body } \\
\text { (leaves) }\end{array}$ & $\begin{array}{c}\text { Number of } \\
\text { branch of } \\
\text { level 1/plant } \\
\text { (branch) }\end{array}$ & $\begin{array}{c}\text { Number } \\
\text { of male } \\
\text { flowers/ } \\
\text { plant } \\
\text { (flower) }\end{array}$ & $\begin{array}{c}\text { Number of } \\
\text { female } \\
\text { flowers/ } \\
\text { plant } \\
\text { (flower) }\end{array}$ & $\begin{array}{c}\text { Number of } \\
\text { fruits/ } \\
\text { plant } \\
\text { (fruit) }\end{array}$ & $\begin{array}{c}\text { Fruit } \\
\text { ratio } \\
(\%)\end{array}$ \\
\hline CT1 & $206.60^{\mathrm{b}}$ & $21.34^{\mathrm{ab}}$ & $4.75^{\mathrm{a}}$ & $47.12^{\mathrm{a}}$ & $7.75^{\mathrm{b}}$ & $2.73^{\mathrm{b}}$ & $68.56^{\mathrm{bc}}$ \\
$\mathrm{CT} 2$ & $208.80^{\mathrm{ab}}$ & $22.23^{\mathrm{a}}$ & $4.83^{\mathrm{a}}$ & $45.50^{\mathrm{a}}$ & $7.92^{\mathrm{b}}$ & $2.83^{\mathrm{ab}}$ & $71.25^{\mathrm{b}}$ \\
$\mathrm{CT3}$ & $210.20^{\mathrm{a}}$ & $23.62^{\mathrm{a}}$ & $5.04^{\mathrm{a}}$ & $44.62^{\mathrm{a}}$ & $8.23^{\mathrm{a}}$ & $2.91^{\mathrm{a}}$ & $74.82^{\mathrm{a}}$ \\
$\mathrm{CT} 4$ & $203.50^{\mathrm{c}}$ & $19.52^{\mathrm{b}}$ & $4.36^{\mathrm{b}}$ & $46.74^{\mathrm{a}}$ & $7.45^{\mathrm{c}}$ & $2.54^{\mathrm{c}}$ & $67.12^{\mathrm{c}}$ \\
$\mathrm{LSD}_{0.05}$ & 2.98 & 2.49 & 0.38 & 2.88 & 0.30 & 0.18 & 2.98 \\
$\mathrm{CV}^{\mathrm{a}}$ & 0.76 & 6.10 & 4.21 & 3.32 & 2.02 & 3.47 & 2.24 \\
\hline
\end{tabular}

Note: The values in the same column with different characters show a statistically significant difference of $95 \%$. 
According to Table 2, the formulas using controlled-release potassium fertilizer with high doses (CT2, CT3) gave the higher value of main stem length, number of leaves per main stem, number of female flowers, number of fruits, and fruiting ratio than the control formula (CT1), of which CT3 was the highest at the $95 \%$ confidence level. Number of branches, number of male flowers in all fertilization formula was not significantly different. CT4 with a low dose of potassium resulted in poor plant growth and development, this figure is suitable with the previous studies [2], [6].

\subsection{Effect of controlled-release fertilizer on cucumber structural morphology}

One of the factors determining the quality of a cucumber is the shape and structure of the fruit. In addition to genetic properties, morphological and structural characteristics are also influenced by weather conditions, fertilizers, and nutritional regimes as well as care regimes. The results in Table 3 show that when fertilizing with controlled-release fertilizers with different doses, fruit peel color did not change. In the formulas of controlled-release fertilizer with high potassium content (CT2, CT3), the fruit length indicator was higher than the control formula (CT1) and the highest recorded in CT3 $(20.13 \mathrm{~cm})$ with $95 \%$ confidence. In all of the formulas, the fruit diameter did not differ significantly, the fruit diameter arranged between $3.95-4.06 \mathrm{~cm}$, the flesh thickness ranged from $1.28-1.36 \mathrm{~cm}$, in which CT3 gave the highest fruit diameter and flesh density.

Table 3. Effects of controlled-release potassium fertilizer on morphological structure

\begin{tabular}{ccccc}
\hline $\begin{array}{c}\text { Fertilizer } \\
\text { formula }\end{array}$ & $\begin{array}{c}\text { Fruit length } \\
(\mathbf{c m})\end{array}$ & $\begin{array}{c}\text { Fruit diameter } \\
(\mathbf{c m})\end{array}$ & $\begin{array}{c}\text { Flesh thickness } \\
(\mathbf{c m})\end{array}$ & Color of peel \\
\hline CT1 & $18.79^{\mathrm{b}}$ & $4.06^{\mathrm{a}}$ & $1.28^{\mathrm{a}}$ & Dark green \\
CT2 & $19.40^{\mathrm{ab}}$ & $4.07^{\mathrm{a}}$ & $1.30^{\mathrm{a}}$ & Dark green \\
CT3 & $20.13^{\mathrm{a}}$ & $4.16^{\mathrm{a}}$ & $1.36^{\mathrm{a}}$ & Dark green \\
CT4 & $18.46^{\mathrm{b}}$ & $3.95^{\mathrm{a}}$ & $1.28^{\mathrm{a}}$ & Dark green \\
$\mathrm{LSD}_{0.05}$ & 1.32 & 0.24 & 0.14 & \\
CV\% & 3.65 & 3.18 & 5.53 & \\
\hline
\end{tabular}

\subsection{Effects of controlled-release potassium fertilizer on productivity and yield components}

Table 4. Effects of controlled-release potassium fertilizers on yield and productivity components

\begin{tabular}{cccccc}
\hline $\begin{array}{c}\text { Fertilizer } \\
\text { formula }\end{array}$ & $\begin{array}{c}\text { Average fruit } \\
\text { weight }(\mathbf{g})\end{array}$ & $\begin{array}{c}\text { Number of } \\
\text { fruits/trees } \\
\text { (fruit) }\end{array}$ & $\begin{array}{c}\text { Theoretical } \\
\text { yield } \\
\text { (ton/ha) }\end{array}$ & $\begin{array}{c}\text { Actual yield } \\
\text { (ton/ha) }\end{array}$ & $\begin{array}{c}\text { In comparison with } \\
\text { control formula } \\
(\%)\end{array}$ \\
\hline $\mathrm{CT} 1$ & $248.34^{\mathrm{c}}$ & $2.76^{\mathrm{a}}$ & $41.13^{\mathrm{b}}$ & $15.62^{\mathrm{c}}$ & 100.00 \\
$\mathrm{CT} 2$ & $253.16^{\mathrm{b}}$ & $2.83^{\mathrm{a}}$ & $42.99^{\mathrm{b}}$ & $17.20^{\mathrm{b}}$ & 110.12 \\
$\mathrm{CT} 3$ & $268.45^{\mathrm{a}}$ & $2.84^{\mathrm{a}}$ & $46.39^{\mathrm{a}}$ & $19.81^{\mathrm{a}}$ & 126.82 \\
$\mathrm{CT} 4$ & $242.61^{\mathrm{d}}$ & $2.54^{\mathrm{b}}$ & $36.97^{\mathrm{c}}$ & $13.31^{\mathrm{d}}$ & 85.21 \\
$\mathrm{LSD}_{0.05}$ & 2.977 & 0.19 & 2.977 & 1.45 & \\
$\mathrm{CV}$ & 0.62 & 3.70 & 3.78 & 4.67 & \\
\hline
\end{tabular}

Note: The values in the same column with different characters show a statistically significant difference of $95 \%$

The results in Table 4 show that controlled-release fertilizer gave average fruit weight ranging from 242.61 - $268.46 \mathrm{~g}$. The formula of fertilizing with high dose of potassium (CT2, CT3) gave higher average fruit weight than the control formula (CT1) and highest in CT3 (268.45 g) with $95 \%$ confidence. The number of fruits per tree ranged from $2.54-2.84$, but this difference was not statistically significant.

When applying different dose of controlled-release potassium fertilizer for cucumbers, the actual yield of fertilizer experiment formulas were significantly different, ranging from 13.31 to 19.81 tons/ha. In which, $\mathrm{CT} 3(84 \mathrm{~kg} \mathrm{~K} \mathrm{O} / \mathrm{ha}$ ) showed the highest actual yield at $95 \%$ confidence 
level and 26.82\% higher in comparison with the control formula. This proves that CT3 provided nutrients for cucumber plants in a balanced and appropriate manner, helping plants grow well and give high yield.

\subsection{Effects of controlled-release potassium fertilizer on pests and diseases}

Cucumbers are plants that are susceptible to pests and diseases. The data in Table 5 shows that when applying controlled-release potassium fertilizer, the cucumber plant increased resistance to diseases, the possibility of infecting pests and diseases of the plant was low, mildew and virus significantly decreased in comparison with the control formula (except CT4), especially at formula CT3, the rate of infection was very low (1 point). Some worms such as green worms, gray worms, amulet worms caused mild to moderate damage to cucumbers (from 1-2 points); they damaged the leaves, affecting photosynthesis of plants, but being treated by spraying, so the level of their damage to the plants was low. Diseases infected only at the end of the lifetime of cucumber plants, so they had little effect on the yield of cucumber. This result is coincident with the previous research of the author [2].

Table 5. Effects of fertilizer on pests and diseases of cucumber plants

\begin{tabular}{ccccccc}
\hline \multirow{2}{*}{$\begin{array}{c}\text { Fertilizer } \\
\text { formula }\end{array}$} & $\begin{array}{c}\text { Green worm } \\
\text { (points) }\end{array}$ & $\begin{array}{c}\text { Gray worm } \\
\text { (points) }\end{array}$ & $\begin{array}{c}\text { Thrips } \\
\text { (points) }\end{array}$ & $\begin{array}{c}\text { Downy } \\
\text { mildew } \\
\text { (points) }\end{array}$ & $\begin{array}{c}\text { Powdery } \\
\text { mildew } \\
\text { (points) }\end{array}$ & $\begin{array}{c}\text { Virus } \\
\text { (points) }\end{array}$ \\
\hline CT1 & 2 & 2 & 2 & 2 & 2 & 3 \\
(control) & 1 & 2 & 2 & 1 & 2 & 1 \\
CT2 & 1 & 1 & 2 & 1 & 1 & 1 \\
CT3 & 2 & 2 & 2 & 2 & 2 & 2 \\
CT4 & 2 & &
\end{tabular}

Note: Downy mildews, powdery mildew, bugs, thrips are evaluated on a 1-5 scale of Asian Vegetable Research and Development Center. Score 1: very good; Score 5: very weak

\section{Conclusion}

The controlled-release of potassium affected some indicators of growth, development, yield, and pest infestation levels in the field of Amata765 cucumbers grown in Dong Hy district, Thai Nguyen province.

Cucumber Amata765 grew and developed favorably in Thai Nguyen, giving high yield when applying controlled-release potassium fertilizer with an amount of 84-120 $\mathrm{kg} \mathrm{K} \mathrm{K}_{2} \mathrm{O} / \mathrm{ha}$. When fertilizing controlled-release potassium fertilizer with an amount of $84 \mathrm{~kg} \mathrm{~K}_{2} \mathrm{O}$ ha, it is the most suitable for the growth and development of the plant, giving the highest yield (19.81 tons/ha), reducing the rate of pests and diseases. When fertilizing with controlled-release potassium fertilizer with the amount of $60 \mathrm{~kg} \mathrm{~K} 2 \mathrm{O} / \mathrm{ha}$, the plants grew weak, giving lower yield than the control. Research results show that controlled-release potassium fertilizer is suitable for the development of cucumber plants; it is necessary to continue research and experiment on other crops for mass application in agricultural production in Vietnam.

\section{REFERENCES}

[1] T. T. Le, M. L. Pham, and T. M. H. Tran, "Determination of some Technical Factors for Cucumber $F_{1}$ Hybrid G11-2 Seed Production in Northern Delta and Midlands," Vietnam Journal of Agricultural Sciences, vol. 18, no. 6, pp. 408 - 413, 2020.

[2] T. T. Le, and T. H. Ngo, "The effect of nitrogen and potasium dosages on the growth, development and yield of cucumber variety GL1-9," Science and Technology Journal of Agriculture \& Rural Development, vol. 3, pp. 137-141, 2020. 
[3] Ministry of Agriculture and Rural Development, National Technical Regulation on Testing for Value of Cultivation and Use of Cucumber Varieties QCVN 01-87-2012, June 19, 2012.

[4] People's Committee of Thai Nguyen province, Decision on approving the project of agricultural restructuring towards increasing added value and sustainable development of Thai Nguyen province, period 2017-2020, No: 2018/QD-People's Committee, July $5^{\text {th }} 2017$.

[5] M. E. Trenkel, Slow-and Controlled - release and Stabilized Fertilizers: An Option for Enhancing Nutrient Use Efficiency in Agriculture. International Fertilizer Industry Association, 2010.

[6] B. Y. Ha, H. R. Kim, D. H. Kim, J. W. Woo, Y. J. Jo, and S. Kwon, "Growth effects of the application of new controlled-release fertilizers on Phalaenopsis spp," Applied Biological Chemistry, vol. 61, no. 6, pp. 625-633, 2018.

[7] X. F. Tian, C. L. Li, M. Zhang, Y. Y. Lu, Y. L. Guo, and L. F. Liu, "Effects of controlled-release potassium fertilizer on available potassium, photosynthetic performance, and yield of cotton," Journal of Plant Nutrition and Soil Science, vol. 180, no. 5, pp. 505-515, 2017.

[8] X. Tian, X. Zhou, Q. Liu, J. W. Peng, W. M. Wang, Z. H. Zhang, Y. Yang, H. X. Song, and C. Y. Guan, "Effects of a controlled-release fertilizer on yield, nutrient uptake, and fertilizer usage efficiency in early ripening rapeseed (Brassica napus L.)," Journal of Zhejiang University-Science B (Biomedicine \& Biotechnology), vol. 17, no. 10, pp. 775-786, 2016.

[9] Y. J. Dong, M. R. He, Z. L. Wang, W. F. Chen, J. Hou, X. K. Qiu, and J. W. Zhang, "Effects of new coated release fertilizer on the growth of maize," Journal of Soil Science and Plant Nutrition, vol. 16, no. 3, pp. 637-649, 2016.

[10] V. P. Nguyen, and T. C. Nguyen, "Effect of Slow-Released Nitrogenous Fertilizer with Polymer Coating on Growth and Yield of Maize in Spring Season in Gia Lam - Ha Noi," Journal of Science and Development - Hanoi University of Agriculture, vol. 10, no. 2, pp. 256-265, 2012.

[11] Q. T. Tran, T. T. Nguyen, T. D. Nguyen, C. H. Do, and T. H. Nguyen, "Effects of slow-release fertilizer on the yield and economic efficiency of commercial tea plantation In Dong Hy district, Thai Nguyen province," TNU Journal of Science and Technology, vol. 161, no. 01, pp. 45-49, 2017.

[12] Q. T. Tran, and V. N. Tran, "Effect of controlled release NPK fertilizer new generation on growth, development and yield of winter-melon no.1 In Song Cong -Thai Nguyen," Journal of Analytical Sciences, vol. 23, no. 3, pp. 181-188, 2018.

[13] Q. T. Tran, "Properties and Nutrition release rate in the soil of slow-release potassium fertilizer via polymer coating layer," TNU Journal of Science and Technology, vol. 208, no. 15, pp. 215-220, 2019.

[14] Q. T. Tran, and V. N. Vu, "Synthesis and properties of Slow-release potash fertilizer," Journal of Analytical Sciences, vol. 24, no. 2, pp. 205-211, 2019. 